\title{
Overexpression of the maize homeo box gene, KNOTTED-1, causes a switch from determinate to indeterminate cell fates
}

\author{
Neelima R. Sinha, Rosalind E. Williams, and Sarah Hake \\ U.S. Department of Agriculture-Agricultural Research Service Plant Gene Expression Center, Albany, California \\ 94710 USA; Department of Plant Biology, University of California, Berkeley, California 94720 USA.
}

\begin{abstract}
The KNOTTED-1 (KN1) locus of maize is defined by dominant mutations that affect leaf cell fates. Transposon tagging led to the isolation of the gene and the discovery that $K N 1$ encodes a homeo domain. Immunolocalization studies showed that in wild-type maize plants, KN1 protein is present in nuclei of apical meristems and immature shoot axes but is down-regulated as lateral organs, such as leaves, are initiated. The protein is not immunohistochemically detectable in wild-type leaves at any stage. In developing leaves of plants carrying the dominant $K n 1$ mutation, temporally and spatially restricted ectopic expression of $K N 1$ causes the mutant phenotype. To better understand the function of KN1 in plant development, we sought to determine the phenotype of plants in which $K N 1$ was constitutively expressed. We find that tobacco plants transformed with the $K N 1$ cDNA driven by the CaMV 35S promoter have a dramatically altered phenotype. The phenotypes are variable and depend on the level of KN1 protein. Plants expressing moderate levels of KN1 are reduced in stature with rumpled or lobed leaves. Plants with relatively high levels of KN1 lack apical dominance and are severely dwarfed in overall height and leaf size. Small shoots originate from the surface of these diminutive leaves. On the basis of phenotypes in maize and tobacco, we propose that the KN1 homeo box gene plays a role in determining cell fate. The consequences of $K N 1$ overexpression appear to depend on the concentration of $\mathrm{KN} 1$ and the timing of its expression during organogenesis.
\end{abstract}

[Key Words: Maize; overexpression; homeo box; morphogenesis; KNOTTED]

Received January 4, 1993; revised version accepted February 16, 1993.

Plants grow as a result of cell division and differentiation of tissues derived from indeterminate meristems (Steeves and Sussex 1989). Meristems are self-maintaining tissues; they regenerate themselves while propagating cells that will form the rest of the plant. The shoot apical meristem contributes to the shoot axis and produces indeterminate branches, which are, in effect, new shoot axes. The apical meristem also forms determinate lateral organs, such as leaves and floral organs. How indeterminate meristems produce determinate organs remains a fundamental question in plant biology.

Recent evidence suggests that the KNOTTED-1 (KN1) gene may play a role in the switch from indeterminate to determinate fates. In wild-type maize plants, the KN1 protein is localized to nuclei of shoot apical meristems and a subset of cells in the shoot axis. It is not present in root meristems that do not produce determinate lateral organs. As lateral organs, such as leaves or floral organs, are initiated, KN1 expression is down-regulated. The down-regulation occurs well before leaves are initiated and may be essential for proper leaf determination (Smith et al. 1992).

The dominant $K n 1$ mutations primarily affect leaf development (Bryan and Sass 1941; Gelinas et al. 1969;
Freeling and Hake 1985). Normal maize leaves are divided into the sheath, which wraps around the stem, and the blade, which tilts out for photosynthetic purposes. At the juncture of the blade and sheath is an epidermal fringe of tissue called the ligule. A series of lateral and intermediate veins extend through the entire leaf perpendicular to the ligule. $K n 1$ mutations affect primarily the lateral veins of the leaf blade. Outgrowths, or knots, form sporadically along the veins of the leaf blade from continued growth of a subset of cells. The ligule is often displaced into the leaf blade or found ectopically in the blade running parallel to the veins. The cells surrounding the lateral veins assume sheath characteristics. The knots can also be considered as sheath transformations because, in wild-type leaves, sheath cells divide and differentiate after such activity has ceased in the blade (Sharman 1942; Sylvester et al. 1990). The Kn1 mutations result from insertions into introns (Hake et al. 1989; Hake 1992) or a tandem duplication (Veit et al. 1990). Neither the size of the transcript nor its normal localization pattern are affected by these dominant mutants. Instead, ectopic KN1 expression occurs at an early stage in leaf development in cells that will form veins in the leaf blade. Models for Kn1 action suggest that the 
expression of $K N 1$ in the leaf prevents the cells from adopting their normal blade cell fate and causes them to differentiate into sheath cells instead (Smith et al. 1992).

A role for homeo box genes in Drosophila development is well established from genetic analysis of homeotic mutants (Gehring 1987). Except for KN1 and members of that gene family /Vollbrecht et al. 1991; P. Becraft, S. Hake, and M. Freeling; J. Fowler and M. Freeling; both unpubl.), plant homeo box genes have not been correlated with mutationally defined loci (Ruberti et al. 1991; Schena and Davis 1992). Plant transformation provides a mechanism with which to manipulate the timing, concentration, and tissue specificity of a particular gene's expression. Such experiments have aided in understanding the role of homeo box genes in a number of animal systems (e.g., see Schneuwly et al. 1987; Niehrs and De Robertis 1991; Morgan et al. 1992) and should expand our understanding of the role of homeo box genes in plant developmental processes. Here, we present evidence that the maize KN1 gene product is functional in tobacco cells and initiates major morphological changes. At low concentrations, KN1 alters leaf shape; at higher concentrations, the leaves produce shoots from their surfaces. On the basis of the phenotype produced with high concentrations of $\mathrm{KN} 1$, we speculate that $K N 1$ may play a role in regulating the switch from indeterminate to determinate cell fates.

\section{Results}

\section{Leaf phenotypes of primary transformants}

We introduced the full-length KN1 cDNA /Vollbrecht et al. 1991) driven by the CaMV 35 S promoter and terminated by nopaline synthase polyadenylation region (NOS) termination sequences (35SKnNOS) into tobacco leaf discs (Horsch et al. 1985) using the binary vector pBIN19 (Bevan 1984). A similar construct (35SGUSNOS-35SKnNOS) placed the $\beta$-glucuronidase gene (GUS) (Jefferson et al. 1987) behind the same promoter in tandem with KN1. All of the vectors carried the neomycin phosphotransferase gene that is selectable on kanamycin.

The KN1 transformants differed strikingly from wildtype tobacco. The phenotypes were variable, although consistent within a single plant. The 33 primary transformants were grouped into four major categories, normal, rumpled, ivy, and shooty, on the basis of their leaf phenotypes (Table 1; and Fig. 1). Six of the primary transformants appeared normal, although some of their kanamycin-resistant $\left(\operatorname{Kan}^{\mathrm{R}}\right)$ progeny had a mildly rumpled phenotype. Eight of the primary transformants were classified as rumpled. These leaves are puckered in appearance from veins that do not elongate as much as surrounding tissues. The rumpled leaves were approximately two times thicker than wild-type leaves with a disorganized palisade parenchyma layer (Fig. 1B). The flowers of the plants in the normal and rumpled categories appeared normal with a five-lobed pink corolla.

The four primary transformants in the ivy category
Table 1. Phenotypic categories of primary transformants

\begin{tabular}{|c|c|c|c|c|}
\hline Phenotype & $\begin{array}{l}\text { Plant } \\
\text { number }\end{array}$ & $\begin{array}{l}\mathrm{Kan}^{\mathrm{s}} \\
\text { progeny/total }\end{array}$ & Ratio & $\begin{array}{l}\text { Insert } \\
\text { number }\end{array}$ \\
\hline \multirow[t]{6}{*}{ Normal } & $6 a$ & $57 / 255$ & $1 / 4.4$ & 1 \\
\hline & KG8 & $19 / 84$ & $1 / 4.4$ & 1 \\
\hline & KG15 & $42 / 177$ & $1 / 4.2$ & 1 \\
\hline & $5 a$ & $52 / 248$ & $1 / 4.8$ & 1 \\
\hline & $4 b$ & $15 / 245$ & $1 / 16.3$ & 2 \\
\hline & $8 c$ & $1 / 560,1 / 176$ & & $3-4^{*}$ \\
\hline \multirow[t]{8}{*}{ Rumpled } & $5 c$ & $44 / 257$ & $1 / 5.8$ & $1-2^{*}$ \\
\hline & $3 \mathrm{a}$ & $21 / 252$ & $1 / 12$ & 2 \\
\hline & KG22 & $15 / 205$ & $1 / 13.6$ & 2 \\
\hline & KG10 & $7 / 103$ & $1 / 14.7$ & 2 \\
\hline & KG18 & $7 / 109$ & $1 / 15.6$ & 2 \\
\hline & $9 \mathrm{a}$ & $14 / 251$ & $1 / 17.9$ & 2 \\
\hline & $2 b$ & $14 / 256$ & $1 / 18.3$ & 2 \\
\hline & $8 \mathrm{~g}$ & $1 / 680$ & & $4-5^{*}$ \\
\hline \multirow[t]{4}{*}{ Ivy } & $7 a$ & $102 / 419$ & $1 / 4$ & 1 \\
\hline & $2 \mathrm{a}$ & $18 / 278$ & $1 / 15.4$ & 2 \\
\hline & $5 b$ & $32 / 516$ & $1 / 16.1$ & 2 \\
\hline & $12 \mathrm{~b}$ & $3 / 251$ & $1 / 84$ & 3 \\
\hline \multirow[t]{15}{*}{ Shooty } & $14 d$ & $30 / 133$ & $1 / 4.4$ & 1 \\
\hline & $14 \mathrm{e}$ & $21 / 133$ & $1 / 6.3$ & $1-2^{*}$ \\
\hline & $6 c$ & $11 / 222$ & $1 / 20.2$ & 2 \\
\hline & 8 & $8 / 311$ & $1 / 39$ & 3 \\
\hline & $11 \mathrm{a}$ & $6 / 250$ & $1 / 42$ & 3 \\
\hline & $15 \mathrm{e}$ & $4 / 241$ & $1 / 60$ & 3 \\
\hline & la & $2 / 126$ & $1 / 63$ & 3 \\
\hline & $11 \mathrm{~b}$ & $4 / 256$ & $1 / 64$ & 3 \\
\hline & $10 \mathrm{e}$ & $3 / 198$ & $1 / 66$ & 3 \\
\hline & $10 \mathrm{c}$ & $3 / 198$ & $1 / 66$ & 3 \\
\hline & $15 c$ & $3 / 197$ & $1 / 66$ & 3 \\
\hline & $9 \mathrm{~d}$ & $1 / 120$ & & 3 \\
\hline & $12 \mathrm{e}$ & $3 / 350$ & $1 / 117$ & 4 \\
\hline & $12 \mathrm{~d}$ & $0 / 254$ & & $>4$ \\
\hline & $9 \mathrm{~b}$ & $0 / 281$ & & $>4$ \\
\hline
\end{tabular}

Self-pollinated seeds from 33 independent transformation events were plated on kanamycin, and the ratio of $\operatorname{Kan}^{\mathrm{S}}$ progeny was determined. The insert number is based on predicted Mendelian ratios. Chi-square tests that gave a probability of $<10 \%$ are indicated with an asterisk. The deviations from expected ratios are likely attributable to recombination between linked inserts.

had more severe phenotypic perturbations. The leaves were twice as thick as wild type, cell size was increased, the palisade parenchyma was absent, and the shape of the leaf was mildly to deeply lobed (Fig. 1C). The lobes of the leaf rarely showed mirror-image symmetry across the mid-vein, and successive leaves on a plant differed from each other in lobe pattern. The flowers were pale pink with dissected corollas.

The 15 primary transformants in the shooty category had thickened leaves of severely reduced size. The cells were large with no distinction between palisade and spongy parenchyma (Fig. ID). As will be discussed later, small shoots initiated from the shooty leaves. The flowers displayed no color at all, and the dissected corollas did not expand. Occasionally, extra anther lobes were present on the surface of the anthers. 


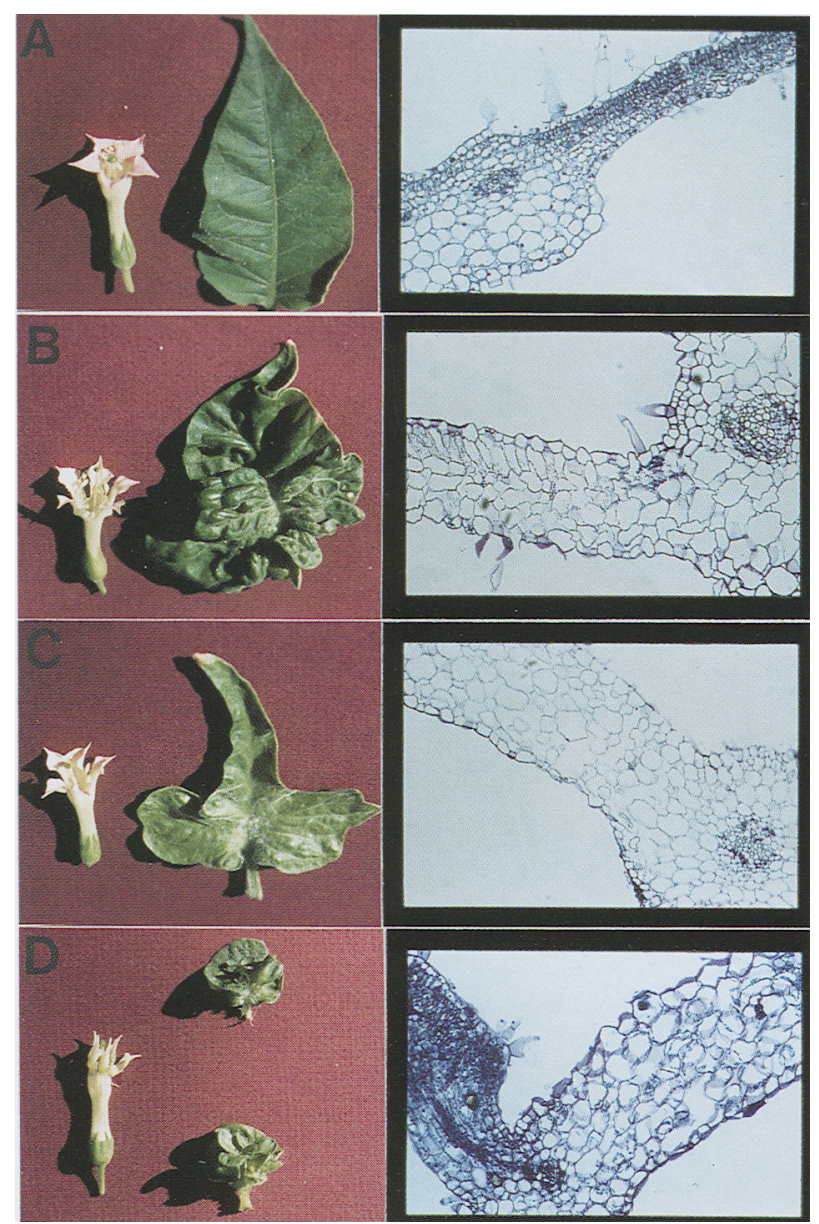

Figure 1. Phenotypes of tobacco plants overexpressing the maize $K N 1$ gene. A typical flower, leaf, and cross section of each category are depicted. (A) Flower and upper leaf of an untransformed tobacco plant. These leaves are smaller than leaves found lower on the plant but have the same shape. $(B)$ Rumpled plant. (C) Ivy plant. $(D)$ Shooty plant.

Overall plant morphology was also altered in the more severe phenotypic categories. The plants were extremely dwarfed as a result of reduced internode elongation. Apical dominance, in which the main shoot inhibits the growth of axillary buds, was entirely absent. After flowering, each plant had many upright floral branches of equal length, giving the appearance of a small bush (Fig. 2). All the plants produced fertile flowers, although the time to flowering was delayed by up to 6 months in the more severe categories.

\section{High levels of KN1 transform leaves into shoot- bearing organs}

Small shoots were often found on the surface of the shooty leaves (Fig. 3). The shoots primarily arose in clusters near the junction between the blade and the petiole but were occasionally found isolated and toward the leaf tip. The shoots were usually associated with the veins of the leaf (Fig. 3B). Some severely dwarfed plants bore shoots on every leaf. These ectopic shoots remained diminutive, never progressing beyond four to five visible leaf primordia. The production of shoots, particularly large numbers of shoots, was often accompanied by a transition in the leaf from a dorsiventrally symmetrical vasculature to a radially symmetrical one characteristic of shoot axes (data not shown).

After the main shoots of the shooty plants flowered, axillary branches from lower nodes often elongated. We refer to these branches as renewal branches. The leaves on the renewal branches produced ectopic shoots that were floral. In contrast to the more limited growth of the vegetative ectopic shoots, these floral shoots elaborated their lateral (floral) organs, often generating entire flowers (Fig. 4).

\section{Severity of phenotype is correlated with increase in $\mathrm{KN} 1$}

The phenotypic variation of the KN1 transgenic plants could result from qualitative variation in transgene expression patterns attributable to the position of the insert in the genome or from quantitative variation owing to differences in the number of $K N 1$ gene copies. The finding of multiple independent events that exhibit similar phenotypes makes position effects unlikely. We investigated the basis for the variation by analyzing the number of inserts in each transformant, observing the phenotype of the progeny and determining the amount of KN1 RNA and protein present. An estimate of the number of independent insertions was obtained by determining the ratio of $\mathrm{Kan}^{\mathrm{S}}$ (kanamycin-sensitive) to $\mathrm{Kan}^{\mathrm{R}}$ plants in the self-pollinated progeny (Table 1). With a few exceptions, one insertion was present in plants of the normal category, two insertions were present in plants of the rumpled and ivy categories, and three insertions were present in the shooty plants. The correlation of insert number with severity suggests that the phenotypic variation is largely dosage dependent.

We also examined the DNA from some of the primary transformants to estimate the number of $K N 1$ gene copies. The inserts rarely contained a single $K N 1$ gene but consisted of tandem copies (data not shown). Thus, the number of KN1 gene copies per transgenic plant is probably greater than the number of insertions estimated by percentage of $\operatorname{Kan}^{\mathrm{R}}$ progeny (Table 1 ).

We observed the phenotype of progeny resulting from self-pollinations of many independent transformants. Individuals from each category gave rise to progeny that conformed to other categories. For example, of 142 seeds planted from a self-pollination of plant $9 \mathrm{~A}$, which was rumpled in appearance (Table 1), we found $\sim 4$ of 16 normal, 6 of 16 mildly rumpled, 5 of 16 severely rumpled individuals, and 1 of 16 shooty (Table 2). Severely rumpled leaves are smaller and thicker than mildly rumpled leaves. If independently segregating dominant factors act additively with $0-1$ factors having no effect; $2-3$ causing the rumpled or ivy phenotype and 4 or more resulting in a shooty phenotype, then following self-pollination of a 
Figure 2. Whole plant phenotypes. (Left) A wild-type tobacco plant; (right) a transformed tobacco plant in the shooty category. Overexpression in tobacco causes loss of apical dominance and severe dwarfing. Relative sizes are demonstrated by the presence in each photograph of the same ruler.

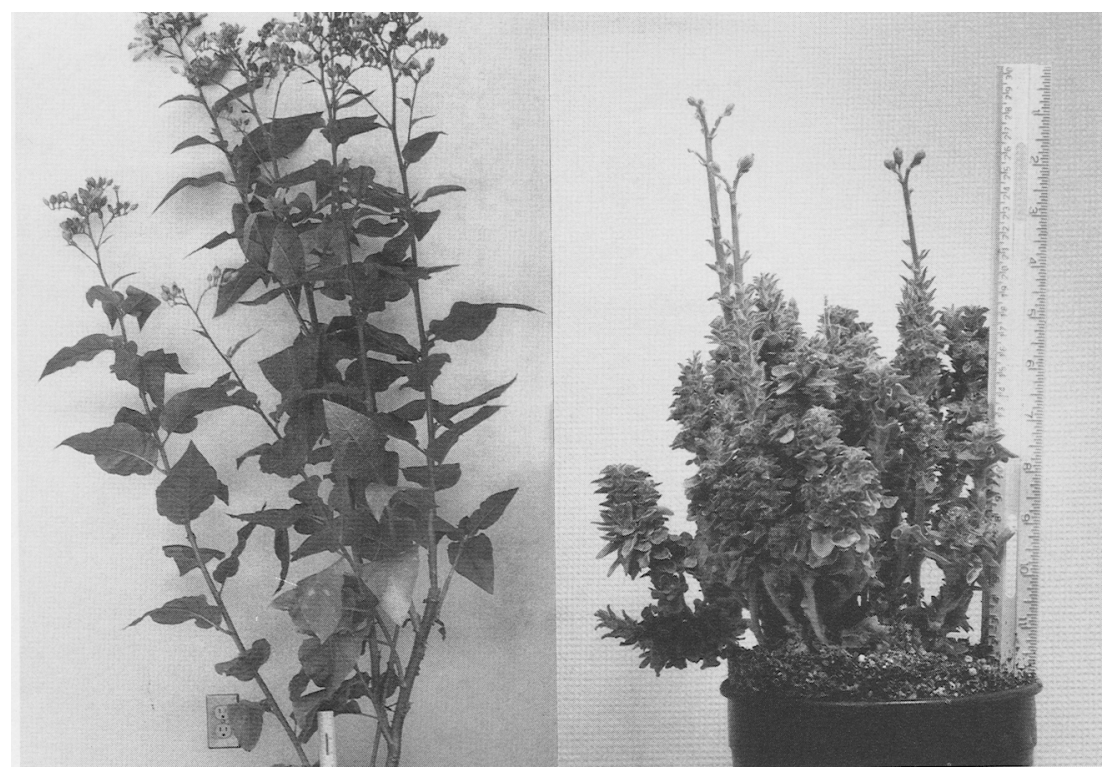

plant carrying two factors, the expected ratios are 5 of 16 for normal $\mid 0-1$ copies $\mid, 6$ of 16 for mildly rumpled $(2$ copies), 4 of 16 for severely rumpled or ivy ( 3 copies), and 1 of 16 for shooty (4 copies). Our data approach the ratios expected if dosage of equally additive factors causes the variation in phenotype; thus, we favor this interpretation over one involving position effects.

The relative levels of KN1 RNA were examined in progeny of the primary transformants. We detected a single 1.6-kb RNA species on RNA blots hybridized with the $K N 1$ probe. More KN1 RNA was detected in progeny of primary transformant $1 \mathrm{~A}$ with a shooty phenotype than progeny with a mildly rumpled phenotype (Fig. 5, lanes 1,2). We also detected a substantial increase in $K N 1$ RNA in an individual that was severely rumpled in comparison with a sibling that was normal appearing (Fig. 5, lanes $3,4 \mid$. No hybridization was seen in RNA isolated from control plants (data not shown). Thus, within a family, higher levels of $K N 1$ RNA were detected in more severely affected individuals.

Total leaf protein extracts from tobacco transformants were subjected to Western analysis using a polyclonal antibody raised against an Escherichia coli-synthesized $\mathrm{KN} 1$ protein (Smith et al. 1992). The protein was detected in extracts isolated from KN1 transgenic plants but not in extracts from control plants (Fig. 6, lane 8). $\mathrm{KN} 1$ protein levels were higher in plants with altered phenotypes than normal-appearing $\mathrm{Kan}^{\mathrm{R}}$ siblings (Fig. 6; progeny of $2 \mathrm{~B}$ and $12 \mathrm{~B}$ ). Protein levels were higher in progeny of the severely rumpled category than the milder rumpled category (Fig. 6 ; progeny of $7 \mathrm{~A}$ and $5 \mathrm{~B}$ ). We also examined severely ivy and severely shooty progeny from 7A. The leaves from the shooty plants had approximately twice as much protein as the severe ivy siblings (data not shown). Comparisons between families, such as $12 B$ and $2 B$, are not as striking, perhaps because of limited position effects or somaclonal variation. The amount of KN1 protein in the severely affected transgenic plants is comparable to $\mathrm{KN} 1$ protein levels in extracts of maize shoot apices (Fig. 6, lane 2).

We examined the cellular localization of $\mathrm{KNl}$ in tobacco to determine whether it localized to the nucleus as was found for maize (Smith et al. 1992). Tissue sections from transformed tobacco plants were labeled with the affinity-purified anti-KN1 antibody, and antibody binding was visualized with silver-enhanced immunogold. We found that the $\mathrm{KNl}$ protein is present in most of the nuclei of tobacco leaves that overexpress KNl (data not shown). The nuclear localization is appropriate for the function of $\mathrm{KNl}$ as a transcriptional regulator.

\section{Discussion}

The maize $K N 1$ gene is thought to play a role in the determination of cell fates. It is expressed in indeterminate cells of the apical meristem and is down-regulated in a region of the apical dome that subsequently expands and initiates foliar organ primordia. Furthermore, cells have altered fates when KN1 is ectopically expressed in the leaf (Smith et al. 1992). We overexpressed KN1 in tobacco to determine the effect of constitutive expression. We find three distinct effects on leaf morphogenesis, the manifestations of which are dosage dependent. The primary effect is a reduction in overall size, the second effect is a change in leaf shape, and the last and most significant effect is a switch from determinate cell fates to indeterminate fates.

Tobacco plants that overexpress $K N 1$ are severely reduced in size. Within a family, higher levels of $\mathrm{KN} 1$ protein are correlated with decreasing size. The small leaf size is attributable to a reduction in cell division and not a lack of expansion because cells in these leaves are 
large. The relative suppression of cell division is consistent with the KN1 localization pattern seen in maize. High levels of $\mathrm{KN} 1$ are found in slowly dividing cells of the maize shoot apex, whereas $\mathrm{KN} 1$ is absent from rapidly dividing leaf cells.

Some of the KN1 overexpression plants have severely lobed leaves instead of the characteristic entire leaf of wild-type tobacco. A number of genetic loci are known that affect leaf shape in dicotyledonous plants. For example, the dominant Lanceolate mutation in tomato changes the normally compound leaf with deeply lobed leaflets into a simple leaf with entire margins (Mathan and Jenkins 1962; Caruso 1968). La/ + leaves are smaller than wild type but contain larger cells (Dengler 1984), similar to the KN1 transgenic tobacco plants. The dominant Okra mutation enhances the lobed phenotype of the cotton leaf, resulting in narrower lobes and deeper

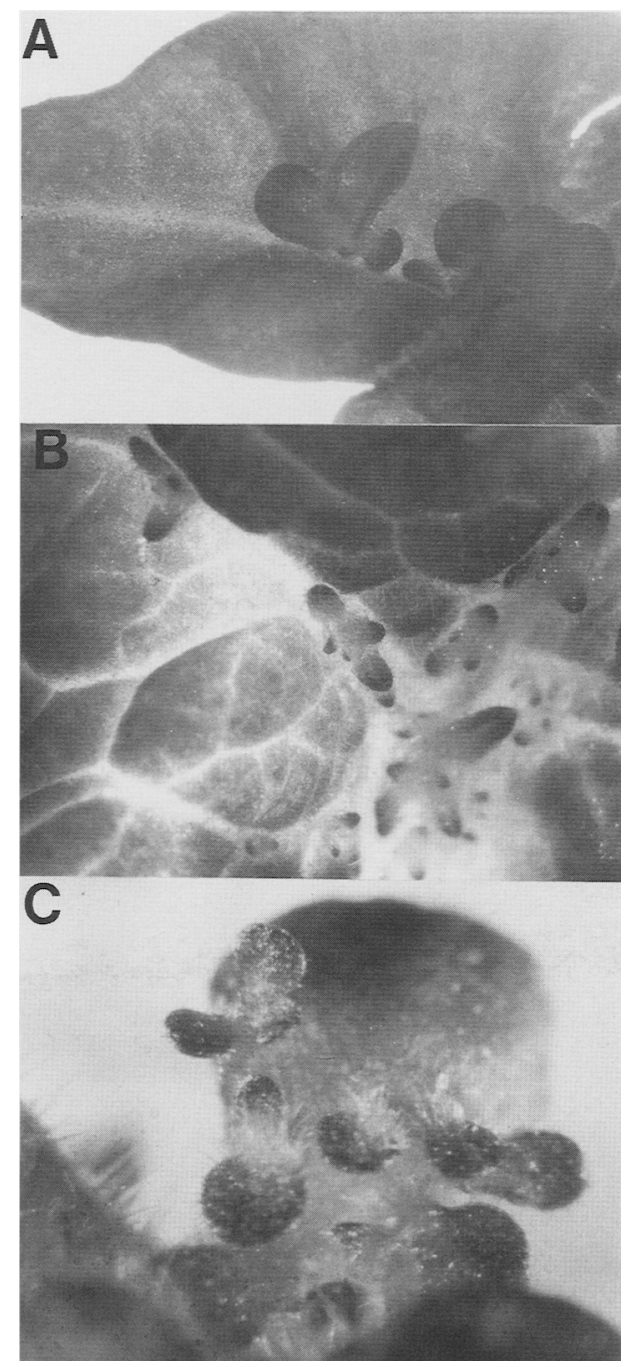

Figure 3. KN1 overexpression results in the production of ectopic shoots on the leaf surface. $\{A, B \mid$ Shoots on leaf surfaces; $|C|$ shoots on cotyledons of progeny from a self-pollinated shooty plant germinated on kanamycin.

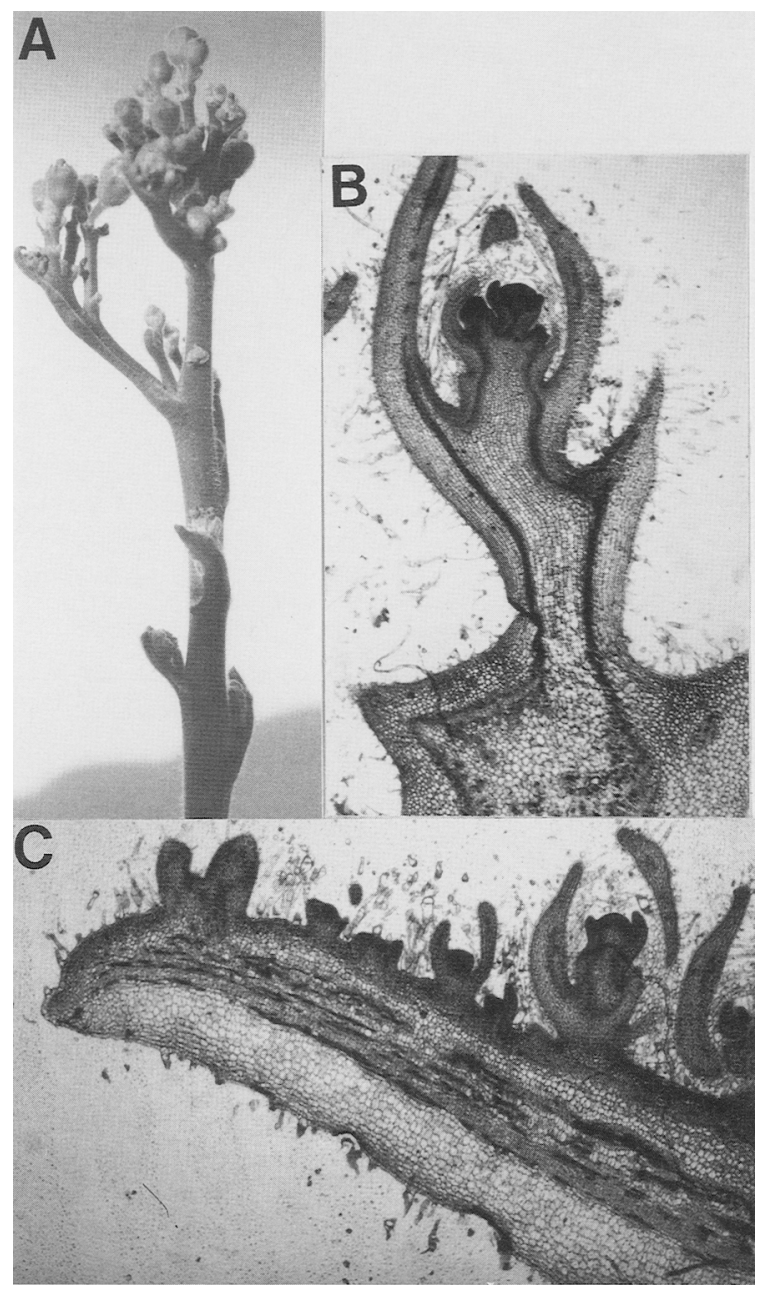

Figure 4. Leaves that produce floral shoots. Plants that have finished flowering sometimes produce branches from the lower nodes. Leaves on these renewal branches bear influorescence primordia. $(A)$ Renewal branch with flower-bearing leaves; $(B)$ transverse section of a leaf with influorescence primordia on the surface $(C)$ longitudinal section of a leaf with influorescence primordia.

sinuses. Allometric measurements demonstrated that the differences in the Okra leaf shape were established at the leaf primordium stage (Hammond 1941a,b) and were cell autonomous (Dolan and Poethig 1991). Aberrant leaf lobing has been found in a number of periclinal chimeras. The lobes are found on plants containing an LII (internal layer adjacent to epidermis) that is inhibited from growing and is sandwiched between an LI (epidermis) and LIII (most internal layer) that are not inhibited from growing. The lobes arise as a result of localized proliferation of the LI layer (for review, see Tilney-Basset 1986).

The mechanisms by which KN1 alters tobacco leaf shape are unknown. The rumpled phenotype, in which the leaves pucker as a result of shortened veins, may reflect a localized decrease in cell division brought about by preferential expression of the CaMV $35 \mathrm{~S}$ promoter in 
Sinha et al.

Table 2. Additive effects of $\mathrm{KN} 1$ insert number

\begin{tabular}{|c|c|c|c|c|c|c|}
\hline Plant number & Phenotype & Inserts & Phenotype of F1 & $\begin{array}{l}\text { Number } \\
\text { observed }\end{array}$ & $\begin{array}{l}\text { Ratio } \\
\text { expected }\end{array}$ & $\begin{array}{l}\text { Ratio } \\
\text { seen }\end{array}$ \\
\hline \multirow[t]{4}{*}{$2 \mathrm{~B}$} & \multirow[t]{4}{*}{ rumpled } & \multirow[t]{4}{*}{2} & normal & $21 / 100$ & $5 / 16$ & $3.4 / 16$ \\
\hline & & & rumpled & $36 / 100$ & $6 / 16$ & $5.8 / 16$ \\
\hline & & & severely rumpled & $35 / 100$ & $4 / 16$ & $5.6 / 16$ \\
\hline & & & shooty & $8 / 100$ & $1 / 16$ & $1.3 / 16$ \\
\hline \multirow[t]{4}{*}{$9 \mathrm{~A}$} & \multirow[t]{4}{*}{ rumpled } & \multirow[t]{4}{*}{2} & normal & $40 / 142$ & $5 / 16$ & $4.5 / 16$ \\
\hline & & & rumpled & $53 / 142$ & $6 / 16$ & $6.0 / 16$ \\
\hline & & & severely rumpled & $42 / 142$ & $4 / 16$ & $4.8 / 16$ \\
\hline & & & shooty & $7 / 142$ & $1 / 16$ & $0.8 / 16$ \\
\hline \multirow[t]{7}{*}{$1 \mathrm{~A}$} & \multirow[t]{7}{*}{ shooty } & \multirow[t]{7}{*}{3} & normal & $3 / 102$ & $1 / 64$ & $1.6 / 64$ \\
\hline & & & mildly rumpled & $13 / 102$ & $6 / 64$ & $6.9 / 64$ \\
\hline & & & severely numpled & $17 / 102$ & $15 / 64$ & $9.1 / 64$ \\
\hline & & & ivy-like & $33 / 102$ & $20 / 64$ & $17.6 / 64$ \\
\hline & & & mildly shooty & $19 / 102$ & $15 / 64$ & $10.1 / 64$ \\
\hline & & & shooty & $15 / 102$ & $6 / 64$ & $8 / 64$ \\
\hline & & & severely shooty & $2 / 102$ & $1 / 64$ & $1.06 / 64$ \\
\hline
\end{tabular}

Expected ratios are based on Mendelian ratios for $0,1,2,3$, and 4 factors in two independent insertions and $0,1,2,3,4,5$, and 6 factors in three independent insertions.

veins (Jefferson et al. 1987; Schneider et al. 1990). There may be other subtle differences in $\mathrm{KNl}$ concentration in the lobed leaves, or regions of the leaf may respond differently to the overall inhibitory effect of $\mathrm{KNI}$ on cell division. Alternatively, KNl may repress the ability of the leaf to grow isometrically, causing each leaf to expand in a random, unique fashion.

High levels of KN1 protein in tobacco leaves result in the production of numerous shoots on the leaf surface. The shoot-bearing leaves are minuscule. Indeterminate leaf-like organs are rare in flowering plants, although they are observed in ferns in which the frond (leaf) is more prominent than the shoot axis and may bear heterotopic buds (Gifford and Foster 1989). An exception in the angiosperms is the common house plant Kalanchoe, which produces shoots on notches in the leaf margin. A more specialized example is seen in the family Meliaceae. Some species in the family have indeterminate leaf-like organs that are considered to be either leaves with extended growth and heterotopic shoot production or mosaic organs with characteristics of the leaf and shoot axis (Fisher and Rutishauser 1990). The production of outgrowths on leaves is seen in some cultivated species like Russian kale and certain begonia species; however, in begonia, these flaps do not originate from a meristem (Maier and Sattler 1977). Whether the production of ectopic shoots in other species results from expression of $K N 1$ homologs in the leaf remains to be determined.

In the context of higher plant evolution, determinate leaf-like organs are a relatively recent addition. The earliest vascular land plants did not produce any leaves but were composed of indeterminate branch systems (Gifford and Foster 1989). Leaf evolution is thought to have involved a change from equal (dichotomous) branching to unequal branching; the leaf evolved from the less prominent branch (for review, see Wilson 1953). Homeo box genes such as KN1 may have contributed toward the distinction between an indeterminate axis and its lateral determinate appendages. For example, plants that evolved mechanisms to repress KN1-like genes may have acquired the ability to evolve determinate leaves.

The production of ectopic shoots on leaves has also

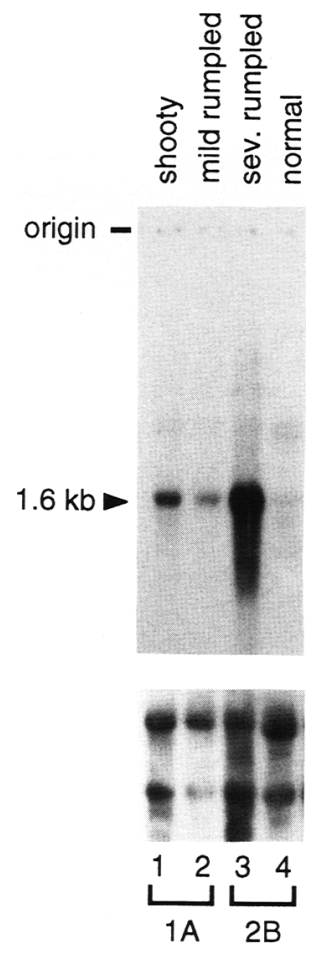

Figure 5. RNA blot analysis of KN1 transgenic plants. Fivemicrogram samples of total RNA isolated from entire small plants were electrophoresed in glyoxal gels, and the resulting Northern blots were probed with the KN1 cDNA /Vollbrecht et al. 1991). The same blots were reprobed with ribosomal DNA probes to provide a control for the amount of RNA loaded on the gel. (Lanes 1,2) Progeny from self-pollination of transformant $1 \mathrm{~A}$ (see Table 1); (lanes 3,4 ) progeny of $2 \mathrm{~B}$. 


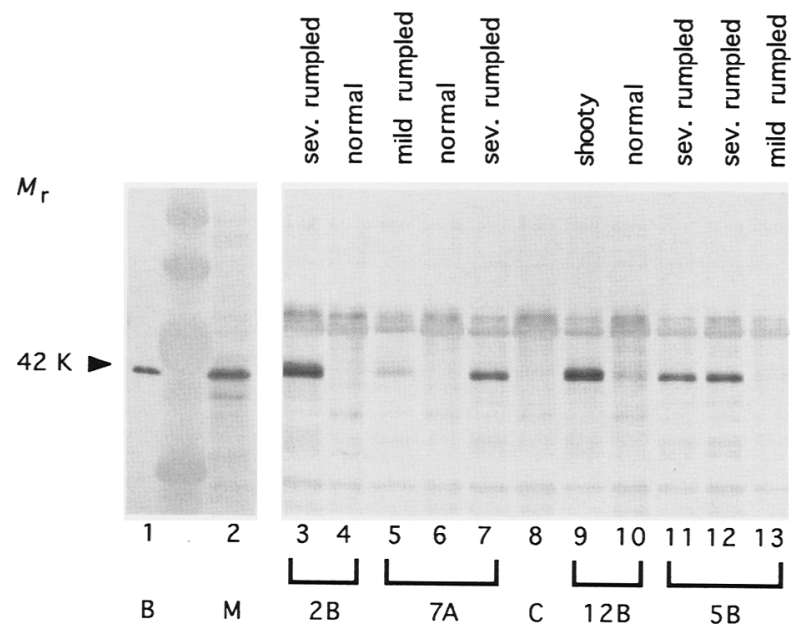

Figure 6. Protein levels of $K N 1$ transgenic tobacco plants. Total protein was extracted from leaves of $\operatorname{Kan}^{\mathrm{R}}$ progeny of transformed plants, and the amount of protein was quantified by Bradford assays. Twenty-microgram samples of total protein were subjected to SDS-PAGE, electroblotted, and analyzed by Western blotting using an anti-KN1 antibody (Smith et al. 1992). (B) Bacterially overexpressed maize $\mathrm{KN} 1$ protein $\mid \sim 10$ $\mathrm{ng})_{;}(\mathrm{M})$ total protein from maize shoot apices; $|C|$ protein from tobacco transformed with a control plasmid, pBII01. Lanes 3-7 and $9-13$ contain protein isolated from $\mathrm{Kan}^{\mathrm{R}}$ progeny. The parent is indicated below the lane, and the phenotypes are indicated above the lanes.

been documented in tobacco plants that overexpress a cytokinin biosynthetic gene (ipt) (Estruch et al. 1991; $\mathrm{Li}$ et al. 1992). Other features of KN1-overexpressing tobacco plants, the loss of apical dominance and the rum. pled leaves, are reminiscent of plants with low auxin levels (Romano et al. 1991) as well as plants that overexpress Agrobacterium rhizogenes Rol genes (Schmülling et al. 1988). The ratios of auxin and cytokinin are critical for the production of shoots or roots in plant tissue culture (Skoog and Miller 1957). The fact that shoots only appeared on transgenic plants with medium levels of cytokinin production rather than high levels $\langle\mathrm{Li}$ et al. 1992) suggests that optimal ratios may be important.

The tobacco transformants share certain characteristics with the KN1 mutants in maize. Phenotypic consequences of ectopic $K N 1$ expression in maize are outgrowths called knots, the production of ligule flaps on the blade, and features of sheath cells in the blade portion of the leaf (Freeling and Hake 1985; Sinha and Hake 1992). The perturbations are specific to cells along the veins and are apparently caused by ectopic expression of $K N 1$ in those veins during leaf development (Smith et al. 1992). Plant height and leaf length are also reduced in maize KN1 mutants. Similar disorganization in photosynthetic cells occurs in both KN1 mutants and KN1 transgenic tobacco plants. The former fail to differentiate bundle sheath cells (Freeling and Hake 1985), and the latter are missing palisade parenchyma cells. We propose that the milder manifestations of ectopic $K N 1$ overexpression are a reduction in growth and altered leaf cell fates in both maize and tobacco. More severe manifestations result when ectopic expression is especially high, in which case leaves acquire indeterminate features. We speculate that constitutive $K N 1$ expression in maize may have consequences similar to those in tobacco.

A number of homeo box genes are thought to act by specifying positional identity (Wolpert 1989). A classic example is the Bicoid gene, which provides positional information to cells along the anterior-posterior axis of the developing Drosophila embryo (Driever and Nüsslein-Volhard 1988). Another example is the regulation of limb morphogenesis by the Hox-4 gene cluster in chicks. Hox4.6 is expressed in digit II primordia and posterior regions of the chick leg bud. When the domain of expression expands into anterior tissues to encompass the primordia of digit $\mathrm{I}$, the number and skeletal elements of digit I resemble those of digit II (Morgan et al. 1992). In plant shoots, the distinction between determinate and indeterminate growth may rely on positional cues that result in the formation of determinate organs in lateral positions while axes remain indeterminate. The effect of KN1 overexpression in tobacco is consistent with the hypothesis that KN1 specifies such positional identity. In wild-type maize plants, $K N 1$ expression is restricted to the meristem and immature shoot axis. When the domain of $K N 1$ expression expands into initiating leaves and $K N 1$ is present at high concentrations, the leaves of the transgenic plants gain characteristics of apical meristems. In accordance with the dosage dependence of positional control, lower concentrations of $\mathrm{KN} 1$ produce different results.

We propose that KN1 forms part of a network of regulatory processes that controls the establishment of indeterminate and determinate identities. In its final implementation, KN1 may utilize changes in ratios of key plant growth regulators. The tobacco phenotype provides a tool for studying the regulation of determinate cell fates as well as identifying essential components of the KN1 gene and other gene family members (Vollbrecht et al. 1991, 1993).

\section{Materials and methods}

Vectors, transformation, and plant regeneration

The maize KN1 cDNA (Vollbrecht et al. 1991) driven by the 430-bp CaMV 35S promoter (Fromm et al. 1986) and containing NOS termination sequences (Fromm et al. 1985) (35SKnNOS) was cloned into the binary vector pBIN19 (Bevan 1984). A similar construct (35SKnNOS-35SGUSNOS) placed GUS (Jefferson et al. 1987) behind the same promoter in tandem with $K N 1$. The vector pBIN19 carrying a 35SGUSNOS construct and a promoterless GUS gene cassette, pBI101 (Clontech), were used as controls in transformations. Transformations of tobacco leaf discs from N. tabacum var. Samsun were performed via Agrobacterium tumefaciens strain LBA4404 (Horsch et al. 1985). $\mathrm{Kan}^{\mathrm{R}}$ regenerants were selected and grown to maturity in the greenhouse. All primary transformants were placed into phenotypic categories and self-pollinated. For pollinations to take place in 
the more severely affected phenotypes, the indehiscent anthers were opened manually to apply pollen to the stigmas.

\section{RNA preparation and Northern and Southern blotting}

RNA isolation and Northern and Southern blotting were performed as described (Hake et al. 1989; Smith et al. 1992). Approximately 5-10 $\mu \mathrm{g}$ of total RNA isolated from leaf tissue was electrophoresed and blotted. Northern and Southern blots were probed with the KN1 cDNA as probe (Vollbrecht et al. 1991). Gels were stained with ethidium bromide, and the degree of staining was recorded photographically to quantitate RNA samples. Northern blots were stripped and reprobed with a ribosomal probe to assess RNA quality and quantity.

\section{Histology and immunolocalization}

Tissue for histology was fixed in formaldehyde/acetic acid/alcohol (FAA) (Berlyn and Miksche 1976) and gradually infiltrated with paraffin through a tertiary butyl alcohol (TBA) series over a period of $2-3$ days. Approximately $10-\mu \mathrm{m}$ thin sections were cut on a rotary microtome (Bausch and Lomb) and attached to polylysine-coated slides. Sections were deparaffinized in Histoclear (National Diagnostics) and stained with toluidine blue (Sakai 1973). Hand sections of fresh tissue were treated with a saturated phloroglucinol solution in $6 \mathrm{~N} \mathrm{HCl}$ (Jensen 1962) to stain for lignin in the vascular tissue.

Immunolocalizations were performed as described (Smith et al. 1992). Fresh tissue was fixed in paraformaldehyde and embedded in Steedman's wax (a mixture of PEG 400 distearate and 1-hexadecanol, Aldrich Chemicals). The slides were incubated with affinity-purified KNl antibodies, as detailed (Smith et al. 1992).

\section{Protein extraction and Western blotting}

Proteins were extracted from leaf tissue and quantitatied by Bradford assays. Total protein $(50 \mu \mathrm{g})$ was subjected to SDSPAGE, stained with $0.1 \%$ Ponceau stain in $5 \%$ acetic acid to verify equal loading, electroblotted, and analyzed by Western blotting using an anti-KNl antibody as described previously (Smith et al. 1992).

\section{Progeny analysis}

Self-pollinated Fl progeny from the primary transformants were analyzed by germinating $\sim 500-1000$ surface-sterilized seeds on $0.1 \mathrm{mg} / \mathrm{ml}$ kanamycin plates. Seedlings were scored for $\mathrm{Kan}^{\mathrm{R}}$ on the basis of the presence of branched roots and green, expanded leaves. In addition, $\sim 500$ seeds from each cross were planted directly into soil, and the phenotype of each individual was scored at weekly intervals. Expected segregations were based on Mendelian ratios for $1,2,3$, or 4 independently segregating factors.

\section{Acknowledgments}

We thank E. Vollbrecht, L. Smith, and R. Martienssen for helpful comments on the manuscript, members of the laboratory for useful discussions, and P. Lemaux for ideas and financial support to R.W. We thank J. Long and C. Brown for technical assistance. S.H. and N.S. were supported by the U.S. Department of Agriculture and the National Science Foundation.

The publication costs of this article were defrayed in part by payment of page charges. This article must therefore be hereby marked "advertisement" in accordance with 18 USC section 1734 solely to indicate this fact.

\section{References}

Berlyn, G.P. and J.P. Miksche. 1976. Botanical microtechnique and cytochemistry. Iowa State University Press, Ames, IA.

Bevan, M. 1984. Binary Agrobacterium vectors for plant transformation. Nucleic Acids Res. 12: 8711-8721.

Bryan, A.A. and J.E. Sass. 1941. Heritable characters in maize. J. Hered. 32: 343-346.

Caruso, J.L. 1968. Morphogenetic effects of a leafless mutant in tomato. Am. I. Bot. 55: 1169-1176.

Dengler, N.G. 1984. Comparison of leaf development in normal $(+/+\mid$, entire $|e / e\rangle)$, and lanceolate $(L a /+\mid$ plants of tomato, Lycopersicon esculentum "Ailsa Craig." Bot. Gaz. 145: 6677.

Dolan, L. and R.S. Poethig. 1991. Genetic analysis of leaf development in cotton. Development (Suppl.) 1: 39-46.

Driever, W. and C. Nüsslein-Volhard. 1988. The bicoid protein determines position in the Drosophila embryo in a concentration-dependent manner. Cell 54: 95-104.

Estruch, J.J., E. Prinsen, H. Van Onckelen, J. Schell, and A. Spena. 1991. Viviparous leaves produced by somatic activation of an inactive cytokinin-synthesizing gene. Science 254: 1364-1367.

Fisher, J.B. and R. Rutishauser. 1990. Leaves and epiphyllous shoots in Chisocheton (Meliaceae): A continuum of woody leaf and stem axes. Can. I. Bot. 68: 2316-2328.

Freeling, M. and S. Hake. 1985. Developmental genetics of mutants that specify Knotted leaves in maize. Genetics 111: 617-634.

Fromm, M.E., L.P. Taylor, and V. Walbot. 1985. Expression of genes transferred into monocot and dicot plant cells by electroporation. Proc. Natl. Acad. Sci. 82: 5824-5828.

. 1986. Stable transformation of maize after gene transfer by electroporation. Nature 319: 791-793.

Gehring, W.J. 1987. Homeo boxes in the study of development. Science 236: 1245-1252.

Gelinas, D., S.N. Postlethwait, and O.E. Nelson. 1969. Characterization of development in maize through the use of mutants. II. The abnormal growth conditioned by the Knotted mutant. Am. J. Bot. 56: 671-678.

Gifford, E.M. and A.S. Foster. 1989. Morphology and evolution of vascular plants, 3rd ed. W.H. Freeman, New York.

Hake, S. 1992. Unraveling the knots in plant development. Trends Genet. 8: 109-114.

Hake, S., E. Vollbrecht, and M. Freeling. 1989. Cloning Knotted, the dominant morphological mutant in maize using $D s 2$ as a transposon tag. $E M B O ~ J .8: 15-22$.

Hammond, D. 194la. The expression of genes for leaf shape in Gossypium hirsutum L. and Gossypium arboreum L. I. The expression of genes for leaf shape in Gossypium hirsutum L. Am. I. Bot. 28: 124-138.

1941b. The expression of genes for leaf shape in Gossypium hirsutum L. and Gossypium arboreum L. II. The expression of genes for leaf shape in Gossypium arboreum $\mathrm{L}$. Am. J. Bot. 28: 138-150.

Horsch, R.B., J.E. Fry, N.L. Hoffman, D. Eichholtz, S.G. Rogers, and R.T. Fraley. 1985. A simple and general method for transferring genes into plants. Science 227: 1229-1231.

Jefferson, R.A., T.A. Kavanagh, and M.W. Bevan. 1987. GUS fusions: $\beta$-Glucoronidase as a sensitive and versatile gene fusion marker in higher plants. EMBO /. 6: 3901-3907.

Jensen, W.A. 1962. Botanical histochemistry: Principles and 
practice. W. H. Freeman, San Francisco, CA.

Li, Y., G. Hagen, and T.J. Guilfoyle. 1992. Altered morphology in transgenic tobacco plants that overproduce cytokinins in specific tissues and organs. Dev. Biol. 153: 386-395.

Maier, U. and R. Sattler. 1977. The structure of the epiphyllous appendages of Begonia hispida var. cucullifera. Can. J. Bot. 55: 264-280.

Mathan, D.S. and J.A. Jenkins. 1962. A morphogenetic study of lanceolate, a leaf-shape mutant in the tomato. Am. J. Bot. 49: 504-514.

Morgan, B.A., J.-C. Ipisua-Belmonte, D. Duboule, and C.J. Tabin. 1992. Targeted misexpression of Hox-4,6 in the avian limb bud causes apparent homeotic transformations. Nature 358: 236-239.

Niehrs, C. and E.M. De Robertis. 1991. Ectopic expression of a homeobox gene changes cell fate in Xenopus embryos in a position-specific manner. EMBO J. 10: 3621-3629.

Romano, C.P., M.B. Hein, and H.J. Klee. 1991. Inactivation of auxin in tobacco transformed with the idoleacetic acidlysine synthetase gene of Pseudomonas savastanoi. Genes \& Dev. 5: 438-446.

Ruberti, I., G. Sessa, S. Lucchetti, and G. Morelli. 1991. A novel class of plant proteins containing a homeodomain with a closely linked leucine zipper motif. $E M B O /$. 10: 1787-1791.

Sakai, W.S. 1973. Simple method for differential staining of paraffin embedded plant material using toluidine blue 0 . Stain Technol. 48: 247-249.

Schena, M. and R.W. Davis. 1992. HD-Zip proteins: Members of an Arabidopsis homeodomain protein superfamily. Proc. Natl. Acad. Sci. 89: 3894-3898.

Schmülling, T., J. Schell, and A. Spena. 1988. Single genes from Agrobacterium rhizogenes influence plant development. EMBO J. 7: 2621-2629.

Schneider, M., D.W. Ow, and S.H. Howell. 1990. The in vivo pattern of firefly luciferase expression in transgenic plants. Plant Mol. Biol. 14: 935-947.

Schneuwly, S., A. Kuroiwa, and W.J. Gehring. 1987. Molecular analysis of the dominant homeotic Antennapedia phenotype. EMBO J. 6: 201-206.

Sharman, B.C. 1942. Developmental anatomy of the shoot of Zea mays L. Ann. Bot. 6: 245-281.

Sinha, N. and S. Hake. 1991. Perturbations in leaf development caused by the dominant knotted-mutation in maize. In Progress in plant growth regulation led. C.M. Karssen, L.C. Van Loon, and D. Vreugdenhill), pp. 360-370. Kluwer, Dordrecht, The Netherlands.

Skoog, F., and C.O. Miller. 1957. Chemical regulation of growth and organ formation in plant tissue cultured in vitro. Symp. Soc. Exp. Biol. 11: 118-131.

Smith, L., B. Greene, B. Veit, and S. Hake. 1992. A dominant mutation in the maize homeobox gene, Knotted-1, causes its ectopic expression in leaf cells with altered fates. Development 116: 21-30.

Steeves, T.A. and I.M. Sussex. 1989. Patterns in plant development, 2nd ed. Cambridge University Press, New York.

Sylvester, A.W., W.Z. Cande, and M. Freeling. 1990. Division differentiation during normal and liguleless-1 maize leaf development. Development 110: 985-1000.

Tilney-Bassett, R.A.E. 1986. Plant chimeras, pp. 80-110. Edward Arnold, London, England.

Veit, B., E. Vollbrecht, J. Mathern, and S. Hake. 1990. A tandem duplication causes the $\mathrm{Kn} 1-\mathrm{O}$ allele of Knotted, a dominant morphological mutant of maize. Genetics 125: 623-631.

Vollbrecht, E., B. Veit, N. Sinha, and S. Hake. 1991. The developmental gene Knotted-1 is a member of a maize homoeobox gene family. Nature 350: 241-243.
Vollbrecht, E., R. Kerstetter, B. Lowe, B. Veit, and S. Hake. 1993. Homeobox genes in plant development: Mutational and molecular analysis. In Evolutionary conservation of developmental mechanisms (ed. A.C. Spradling), pp. 111-123. Wiley-Liss, New York.

Wilson, C.L. 1953. The telome theory. Bot. Rev. 19: 417-437.

Wolpert, L. 1989. Positional information revisited. Development (Suppl.): 3-12. 


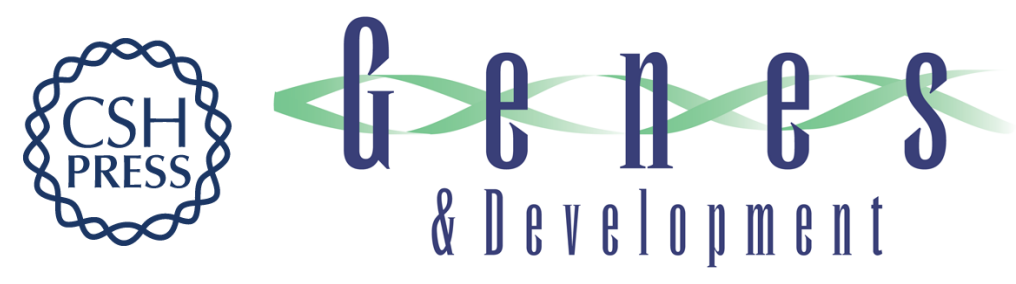

\section{Overexpression of the maize homeo box gene, KNOTTED-1, causes a switch from determinate to indeterminate cell fates.}

N R Sinha, R E Williams and S Hake

Genes Dev. 1993, 7:

Access the most recent version at doi:10.1101/gad.7.5.787

References This article cites 38 articles, 10 of which can be accessed free at:

http://genesdev.cshlp.org/content/7/5/787.full.html\#ref-list-1

License

Email Alerting

Service top right corner of the article or click here.

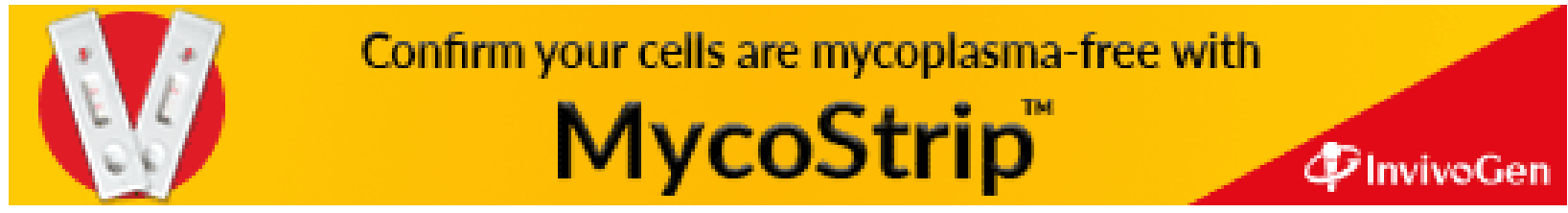

